\title{
STUDI KOMPARATIF PENGGUNAAN MODEL COOPERATIVE LEARNING TIPE NUMBERED HEADS TOGETHER (NHT) DAN ROUND TABLE TERHADAP KEMAMPUAN BERPIKIR KRITIS SISWA
}

\author{
(Studi Komparatif Pada Mata Pelajaran Ekonomi di Kelas XI IPS \\ di SMA Negeri 1 Kuningan)
}

Oleh: Dr. Pupu Saeful Rahmat, M.Pd.

\section{Abstrak}

Tujuan dari penelitian ini adalah untuk mengetahui adanya perbedaan peningkatan kemampuan berpikir kritis siswa sebelum dan setelah proses pembelajaran pada mata pelajaran ekonomi dengan menggunakan model Cooperative Learning tipe Numbered Heads Together (NHT) dan Round Table pada dua kelas eksperimen yang berbeda.

Metode yang digunakan dalam penelitian ini yaitu metode eksperimen. Dalam penelitian ini subjek terdiri dari dua kelas yaitu kelas XI IPS 1 ( kelas eksperimen yang menggunakan tipe NHT) dan kelas XI IPS 2 ( kelas eksperimen yang menggunakan tipe round table). Pengumpulan data dilakukan dengan tes pilihan ganda. Pengolahan data dilakukan dengan melakukan uji normalitas, homogenitas dan $\mathrm{N}$-gain dengan uji t guna mendapatkan nilai perbedaan kedua kelas.

Hasil penelitian menunjukkan bahwa terdapat perbedaan peningkatan kemampuan berpikir kritis siswa yang signifikan antara tipe pembelajaran Numbered Heads Together (NHT) dengan tipe pembelajaran Round Table. Berdasarkan hasil penelitian tersebut dapat disimpulkan bahwa kegiatan belajar dengan menggunakan kedua Tipe tersebut dapat meningkatkan kemampuan berpikir kritis siswa. Tetapi dari hasil penelitian tersebut dinyatakan bahwa tipe Round Table lebih sesuai diterapkan untuk meningkatkan kemampuan berpikir kritis siswa. Sehingga Tipe round table dinyatakan efektif dan dapat digunakan sebagai alternatif metode pembelajaran.

Kata Kunci : kemampuan berpikir kritis siswa, Tipe Numbered Heads Together (NHT, tipe Round Table.

\section{Pendahuluan}

pembelajaran, karena proses pembelajaran yang sering ditemukan selama ini siswa hanya diarahkan untuk menghafal. Kemampuan siswa yang perlu dikembangkan adalah kemampuan berpikir kritis. Dengan berpikir kritis, tentu proses belajar lebih kompleks yang lebih mendalam. Kemampuan ini mendorong siswa untuk merespon suatu masalah dan menemukan solusi terbaik untuk masalah tersebut.

Kemampuan berpikir kritis yang rendah disebabkan kurangnya usaha pembentukan dan penanaman kebiasaan bersikap dan berfikir kritis sejak dini. Sekolah sebagai institusi pendidikan utama dan mendasar bagi perkembangan individu kurang mengkoordinasikan sikap dan pemikiran kritis secara optimal. Sehingga masalah ini berkelanjutan dan menyebabkan siswa cenderung pasif. Rendahnya persentase hasil tes kemampuan berpikir kritis siswa tersebut dikarenakan karena siswa tidak memahami dan sulit menguasai konsepkonsep ekonomi dan masih banyaknya siswa yang nilai hasil belajarnya masih rendah. Dari hasil pengamatan diduga 
guru lebih sering menggunakan model konvensional yaitu metode ceramah sehingga siswa tidak mendapatkan kesempatan untuk mengembangkan potensi berfikirnya terutama pada level kognitif tinggi seperti analisis (C4), sintesis (C5), dan evaluasi (C6), melainkan bergerak pada level kognitif rendah saja seperti pengetahuan (C1), pemahaman (C2) dan aplikasi (C3).

Proses pembelajaran ekonomi yang dilakukan oleh banyak guru saat ini cenderung pada pencapaian target materi kurikulum, yaitu lebih mementingkan pada penghafalan konsep bukan pada pemahaman, dan masih sedikit yang mengacu pada pelibatan siswa. Hal ini akan berpengaruh pada perolehan dan hasil belajar siswa terutama pada kemampuan berpikir kritis siswa.

Solusi untuk meningkatkan kemampuan berpikir kritis siswa melalui guru yaitu dengan menyesuaikan metode pembelajaran. Tidak semua metode pembelajaran dapat meningkatkan kemampuan berpikir kritis. Hal ini sejalan dengan pendapat Jaromelik (Solihatin dan Raharjo, 2008 : 1) mengemukakan bahwa ketepatan guru dalam memilih model dan metode pembelajaran akan berpengaruh terhadap keberhasilan dan hasil belajar siswa karena model dan metode pembelajaran yang dipilih guru berpengaruh terhadap kualitas proses belajar mengajar yang dilakukannya.

Berdasar pada permasalahan tersebut, proses pembelajaran ekonomi harus dipertimbangkan kembali, karena ternyata model dan metode yang selama ini digunakan di SMA Negeri 1 Kuningan belum mampu mengembangkan kemampuan berpikir kritis siswa. Sedangkan siswa harus dididik dan dilatih menggunakan keterampilan berpikir kritis untuk memadukan konsep dan kondisi riil di lapangan. Salah satu model pembelajaran yang direkomendasikan untuk mengatasi permasalahan tersebut adalah model pembelajaran cooperative learning. Untuk membantu siswa dalam meningkatkan kemampuan kemampuan berpikir kritis dalam penelitian ini digunakan model pembelajaran tipe round table dan numbered heads together. Tipe pembelajaran ini mengacu pada upaya merangsang proses berpikir kritis yang sistematis. Maka dalam penelitian ini, penulis mencoba untuk membandingkan penerapan model pembelajaran cooperative learning tipe round table dan numbered heads together di dalam kelas sebagai upaya untuk meningkatkan kemampuan berpikir kritis siswa.

Berdasarkan permasalahan seperti yang telah diuraikan di atas, masalah dalam penelitian ini dirumuskan sebagai berikut:

1) Apakah terdapat perbedaan kemampuan berpikir kritis siswa pada mata pelajaran ekonomi antara kelas yang menggunakan model cooperative learning tipe numbered heads together (NHT) dan tipe round table sebelum perlakuan?

2) Apakah terdapat perbedaan kemampuan berpikir kritis siswa pada mata pelajaran ekonomi antara kelas yang menggunakan model cooperative learning tipe numbered heads together (NHT) dan tipe round table setelah perlakuan?

3) Tipe manakah yang lebih efektif dalam meningkatkan kemampuan berpikir kritis siswa antara tipe round table dengan tipe numbered heads together (NHT) ? 


\section{Kajian Teori}

Berbicara mengenai berpikir kritis, berbicara mengnai berpikir tingkat tinggi. Ennis Arthur L Costa (Sarlito Wirawan Sarwono, 1996) menggambarkan bahwa berpikir kritis adalah: "using basic thinking processes to analyze arguments and generate insight into particular meanings and interpretation; also known as directed thinking".

Pada bagian lain, Anggelo (Arief Achmad, 2007), menyatakan bahwa, "berpikir kritis adalah mengaplikasikan rasional, kegiatan berpikir yang tinggi, yang meliputi kegiatan menganalisis, mensintesis, mengenal permasalahan dan pemecahannya, menyimpulkan, dan mengevaluasi".

Kemampuan berpikir memegang peranan besar dalam peningkatan kualitas individu. Salah satu kemampuan berpikir yang harus dimiliki oleh setiap individu adalah kemampuan berpikir kritis. Berpikir kritis sangat diperlukan mempersiapkan diri dalam menghadapi dan memecahkan permasalahan.

Wade (2009: 45) mengidentifikasi delapan karakteristik berpikir kritis, yakni meliputi:

1) kegiatan merumuskan pertanyaan,

2) membatasi permasalahan,

3) menguji data-data,

4) menganalisis berbagai pendapat dan bias,

5) menghindari pertimbangan yang sangat emosional,

6) menghindari penyederhanaan berlebihan,

7) mempertimbangkan berbagai interpretasi, dan

8) mentoleransi ambiguitas.

Model pembelajaran yang digunakan dalam penelitian ini cooperative learning. Cooperative
Learning dikembangkan berdasarkan teori belajar konstruktivis. Hal ini terlihat pada salah satu teori Vygotsky, yaitu penekanan pada hakikat sosiokultural dari pembelajaran, Vigotsky meyakini bahwa fungsi mental yang lebih tinggi pada umumnya muncul dalam diskusi atau kerjasama antar individu sebelum fungsi mental yang lebih tinggi itu terserap ke dalam individu.

Jonhson (Isjoni, 2010 : 15) mendefinisikan cooperative learning sebagai berikut:

"Cooperative learning working together to accomplish shared goals. Within cooperative activities individuals seek outcomes that are beneficial to all other groups members cooperative learning is the instructional se of small groups that allows students to work together to maximize their own and each other as learning"

Cooperative Learning merupakan suatu model pembelajaran dimana pembelajar yang memiliki tingkat kemampuan berbeda belajar bersama dalam kelompok-kelompok kecil yang heterogen. Dalam menyelesaikan tugas kelompok, setiap anggota saling bekerjasama dan membantu untuk memahami suatu bahan pembelajaran. Belajar belum selesai jika salah satu teman dalam kelompok belum menguasai bahan pembelajaran yang diberikan. Tujuan utama dalam penerapan model belajar mengajar cooperative learning adalah agar peserta didik dapat belajar secara berkelompok bersama teman-temannya dengan cara saling menghargai pendapat dan memberikan kesempatan kepada orang lain untuk mengemukakan gagasannya dengan menyampaikan pendapat mereka secara berkelompok. 
Model Pembelajaran kooperatif tipe numbered heads together (NHT) merupakan tipe yang dirancang untuk mempengaruhi pola interaksi siswa dan memiliki tujuan untuk meningkatkan penguasaan akademik. Menurut Lie (2008 : 59) tipe ini dikembangkan oleh Spencer Kagan dengan melibatkan para siswa pemahaman mereka terhadap isi pelajaran tersebut. Tipe ini memberikan kesempatan kepada siswa untuk mengembangkan ide dan mempertimbangkan jawaban yang paling tepat. Selain itu, tipe ini juga mendorong siswa untuk meningkatkan semangat kerjasama mereka.

Dalam pembelajaran yang menggunakan tipe NHT, siswa lebih bertanggung jawab terhadap tugas yang diberikan karena dalam tipe pembelajaran ini siswa dalam kelompok diberi nomor yang berbeda dan tiap anggota tahu bahwa hanya satu murid yang akan diapanggil untuk mempresentasikan jawaban. Setiap kelompok melakukan diskusi untuk berbagai informasi antar anggota sehingga setiap anggota mengetahui jawabannya.

Tipe pembelajaran kooperatif lainnya yang digunakan dalam penelitian ini yaitu Round table yaitu tipe pembelajaran koperatif yang berguna untuk mengembangkan kemampuan berpikir, meninjau dan berlatih keterampilan. Model kooperatif tipe rond table diciptakan oleh Spencer Kagan pada tahun 1992 dan dikembangkan oleh Anita Lie pada tahun 2002. Lie (2007:63) mengungkapkan bahwa tipe ini bisa digunakan dalam semua mata pelajaran dan untuk semua tingkat anak usia didik.

Dalam Round table, perbedaan ide yang dikemukakan masing-masing anggota kelompok akan mendorong kreativitas dan berpikir lebih dalam.
Kegiatan ini membangun saling ketergantungan positif antara anggota tim, tetapi yang lebih penting yaitu membangun kohesi tim dan memperkuat kekuatan kerja tim, karena siswa melihat dalam tindakan nilai beberapa sudut pandang dan ide.

$$
\text { Keunggulan dari tipe }
$$

pembelajaran round table adalah adanya keterkaitan positif antar anggota kelompok. Ide-ide yang dikembangkan oleh masing-masing anggota kelompok saling ketergantungan, jadi setiap anggota kelompok didorong untuk berpikir ke arah pemikiran yang sama. Jika ada salah satu anggota kelompok yang berhenti mengemukakan idenya maka lebih baik mengatakan pass daripada merubah pola pemikiran yang telah dibangun oleh tim dalam kelompoknya.

Tipe pembelajaran round table menuntut siswa untuk berpikir mengembangkan konsep-konsep dengan pengetahuan baru. Dalam metode round table peran siswa tidak hanya berperan sebagai penyampai gagasan tetapi juga berperan sebagai penyimak gagasan yang disampaikan oleh siswa lainnya.

Model cooperative learning tipe round table merupakan metode pembelajaran dimana siswa belajar dalam kelompok kecil yang terdiri dari 4-5 orang yang heterogen. Setiap orang mempunyai tanggung jawab untuk memecahkan permasalahan yang diberikan oleh guru, dan menganalisis jawaban dari anggota kelompok yang lain. Pembelajaran ekonomi menggunakan model pembelajaran cooperative learning dengan tipe round table diharapkan bisa meningkatkan prestasi siswa. Karena dengan tipe ini siswa dapat mengkontruksi pembelajaran sendiri tanpa dibatasi materi dari guru saja. 
Berdasarkan paparan konsep yang terdapat pada kerangka pemikiran dan latar belakang masalah maka penulis

1) Tidak terdapat perbedaan kemampuan berpikir kritis siswa sebelum menggunakan model cooperative learning tipe round table dan tipe numbered heads together.

2) Terdapat perbedaan kemampuan berpikir kritis siswa setelah menggunakan model cooperative learning tipe round table dan tipe numbered heads together.

3) Model pembelajaran kooperatif tipe round table lebih baik daripada model pembelajaran kooperatif tipe numbered heads together (NHT) dalam meningkatkan kemampuan berpikir kritis siswa.

\section{Metode Penelitian}

Subjek dalam penelitian ini adalah siswa-siswi kelas XI di SMA Negeri 1 Kuningan. Setelah peneliti menyimpulkan terdapat beberapa hipotesis sebagai berikut:

melakukan penelitian di beberapa kelas, terpilih kelas XI IPS 2 sebagai kelompok yang dikenakan model pembelajaran cooperative learning melalui tipe round table, sedangkan kelas XI IPS 1 sebagai kelompok yang menggunakan model pembelajaran cooperative learning melalui tipe numbered heads together.

komparatif. Dalam penelitian ini variabel yang dibandingkan adalah tipe pembelajaran round table dan tipe pembelajaran numbered heads together dengan subjek penelitian yang sama.

Desain yang digunakan dalam penelitian ini yaitu the static-group comparasion. The static-group comparasion melibatkan dua kelompok nonrandomly. Desain penelitian yang digunakan dalam penelitian ini dapat digambarkan sebagai berikut :

Tabel 1

Desain Penelitian

\begin{tabular}{|c|c|c|c|}
\hline $\begin{array}{c}\text { Group } \\
\text { (Kelas) }\end{array}$ & Pretest & $\begin{array}{c}\text { Treatment / } \\
\text { Perlakuan }\end{array}$ & Posttest \\
\hline$A$ & $\mathrm{O}_{1}$ & $\mathrm{X}$ & $\mathrm{O}_{3}$ \\
\hline $\mathrm{B}$ & $\mathrm{O}_{2}$ & $\mathrm{X}$ & $\mathrm{O}_{4}$ \\
\hline
\end{tabular}

Keterangan:

$\mathrm{O}_{1}$ : prestasi siswa pada kelompok A sebelum diberikan perlakuan

$\mathrm{O}_{2}$ : prestasi siswa pada kelompok B sebelum diberikan perlakuan

$\mathrm{O}_{3}$ : prestasi siswa pada kelompok A setelah diberikan perlakuan

$\mathrm{O}_{4}$ : prestasi siswa pada kelompok B setelah diberikan perlakuan

$X$ : Kedua grup sama-sama diberikan perlakuan baru, grup yang pertama (kelas A) diberikan perlakuan berupa tipe numbered heads together dan grup yang kedua (Kelas B) diberi perlakuan berupa tipe round table.
Dalam penelitian ini disusun langkah-langkah penelitian yang merupakan deskripsi runtutan logis langkah-langkah penelitian yang mengaitkan data empiris yang akan dikumpulkan dengan pertanyaan awal penelitian. Runtutan langkah penelitian ini digunakan sebagai acuan logis dalam melakukan penelitian. Langkah-langkah penlitian ini dapat digambarkan sebagai berikut.

a) Penelitian dimulai dengan studi literatur untuk mengkaji Standar Kompetensi dan Kompetensi Dasar 
pada materi pelajaran ekonomi

melalui buku pelajaran Ekonomi

SMA. Hal ini dilakukan secara bersamaan untuk diperoleh informasi mengenai indikator yang sesuai untuk materi. Hasil kajian studi literatur digunakan sebagai acuan dalam pembuatan instrument penelitian yang terdiri dari tes pilihan ganda dan uraian.

b) Pembuatan kisi-kisi tes pilihan ganda dan uraian.

c) Validasi tes pilihan ganda dan uraian yang telah dibuat oleh beberapa ahli yaitu dosen pembimbing.

d) Revisi instrumen dilakukan setelah mendapat masukkan dari validator.

e) Uji coba instrumen penelitian terhadap siswa kelas XII IPS yang telah mempelajari materi tersebut. Uji coba instrumen penelitian bertujuan untuk menghitung reliabilitas tes dan memprediksi hasil penelitian sebenarnya.

f) Setelah hasil analisis uji coba instrumen penelitian diperoleh, dilakukan revisi tes bersama dengan dosen pembimbing.

g) Pelaksanaan tes tertulis terhadap siswa kelas XI IPS yang menggunakan tipe pembelajaran round table dan numbered heads together untuk pengumpulan data penelitian.

h) Setelah data penelitian diperoleh dilakukan pengolahan data terhadap tes tersebut.

i) Membandingkan hasil tes pada kelompok yang menggunakan tipe pembelajaran round table dan numbered heads together.

j) Setelah data diperoleh maka dilakukan pengolahan data dengan menggunakan uji normalitasi, homogenitas dan uji hipotesis.

k) Membuat kesimpulan berdasarkan pada rumusan masalah penelitian.

\section{Hasil Penelitian dan Pembahasan}

Penelitian ini berupa jenis penelitian eksperimen dengan menggunakan metode studi komparatif sehingga dalam penelitian ini peneliti menggunakan dua kelas eksperimen, yaitu satu kelas menggunakan tipe pembelajaran numbered heads together (NHT) sedangkan kelas yang kedua menggunakan tipe pembelajaran round table.

Kelas eksperimen NHT dalam penelitian ini adalah siswa kelas XI IPS 1 tahun pelajaran 2016/2017 sebanyak 35 siswa. Berdasarkan hasil penelitian, diketahui bahwa jumlah siswa laki-laki dikelas eksperimen ini lebih sedikit dibandingkan siswa perempuan, dimana jumlah siswa laki-laki sebanyak 15 siswa sedangkan siswa perempuan sebanyak 20 siswa. Untuk mengetahui lebih jalas jumlah dan persentasenya dapat dilihat pada tabel dibawah ini:

Kelas eksperimen yang menggunakan tipe round table dalam penelitian ini adalah siswa kelas XI IPS 2 tahun pelajaran 2016/2017 sebanyak 35 siswa. Berdasarkan hasil penelitian, diketahui bahwa jumlah siswa laki-laki di kelas eksperimen ini lebih banyak dibandingkan siswa perempuan, dimana jumlah siswa laki-laki sebanyak 19 siswa sedangkan siswa perempuan sebanyak 16 siswa. Untuk mengetahui lebih jalas jumlah dan persentasenya dapat dilihat pada tabel di bawah ini:

Data yang diperoleh dari penelitian ini berupa kemampuan berpikir kritis yang diperoleh dari hasil pre test dan post test. Pemberian pre test dilakukan untuk mengetahui kemampuan berpikir kritis awal siswa dan pemberian post test dilakukan untuk mengetahui kemampuan berpikir kritis siswa setelah dilakukan model pembelajaran dengan masing-masing penerepan model dengan tipe yang berbeda pada kelas eksperimen, antara 
kelas eksperimen yang menggunakan tipe numbered heads together (NHT) dengan kelas eksperimen yang menggunakan tipe round table.

Kemampuan berpikir kritis siswa pada kelas eksperimen yang menggunakan tipe Numbered heads together (NHT) meningkat, hal tersebut dilihat dari data hasil pretest dan post test yang cenderung meningkat pada setiap kali dilakukan eksperimen. Total rata-rata preetest pada kelas ini adalah sebesar 169,66 sedangkan nilai ratarata posttest adalah sebesar 246,33. Hal tersebut menunjukkan bahwa kemampan berpikir kritis siswa pada kelas Numbered heads together (NHT) meningkat. Untuk lebih jelasnya, maka dapat dilihat pada gambar berikut ini:

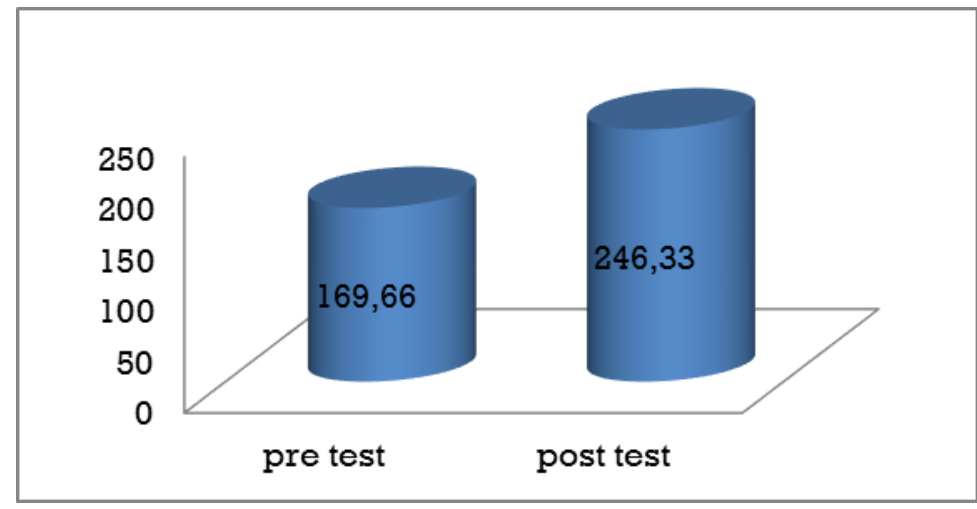

\section{Gambar 1 \\ Nilai pre test dan post test siswa kelas Eksperiman (kelas NHT)}

Data hasil pretes dan posttest kelas eksperimen Numbered Heads Together (NHT) dapat diketahui bahwa kemampuan berpikir kritis siswa pada kelas eksperimen yang menggunakan tipe NHT meningkat, hal tersebut dilihat dari data hasil pretest dan post test yang cenderung meningkat pada saat dilakukan eksperimen.

Kemudian untuk kelas eksperimen (kelas round table), Kemampuan berpikir kritis siswa pada kelas eksperimen yang menggunakan tipe round table meningkat, hal tersebut dilihat dari data hasil pretest dan post test yang cenderung meningkat pada saat dilakukan eksperimen. Total rata-rata preetest pada kelas ini adalah sebesar 169,66 sedangkan nilai rata-rata posttest adalah sebesar 288,66. Hal tersebut menunjukkan bahwa kemampan berpikir kritis siswa pada kelas round table meningkat. Untuk lebih jelasnya, maka dapat dilihat pada gambar berikut ini:

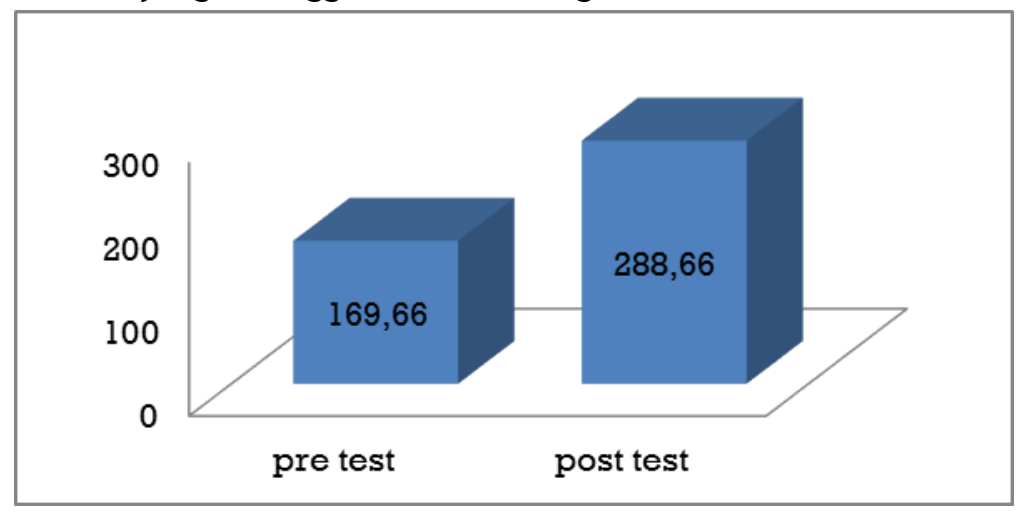


Gambar 2.

Nilai preetest dan post test kelas eksperimen Round table

Berdasarkan data hasil test di kedua kelas, menunjukan bahwa hasil post test kelas round table lebih besar dibandingkan dengan kelas Numbered heads together (NHT).

Skor gain merupakan selisih post test dengan pre test. Skor diperoleh dari hasil pre test dan post test yang diakukan oleh siswa. Setelah data hasil pre test dan post test dari kedua kelas didapat kemudian diolah menggunakan SPSS versi 20,0 for windows untuk mengetahui perbedaan dari penggunaan model pembelajaran Cooperatif Learning tipe Numbered Heads Together dan penggunaan Model pembelajaran Cooperatif Learning tipe Round table. Hasil dari pengolahan tersebut dituangkan dalam tabel 3 berikutnya.

Tabel 3

Deskripsi Skor Gain

\begin{tabular}{|c|c|c|c|c|c|}
\hline & $\mathrm{N}$ & Mean & Std. Deviation & Minimum & Maximum \\
\hline gainNHT & 35 & 6.6857 & 2.37352 & 3.00 & 12.00 \\
GainRT & 35 & 10.2000 & 1.74558 & 7.00 & 14.00 \\
\hline
\end{tabular}

Sumber hasil pengolahan data SPSS 20.0 for windows

Berdasarkan data pada Tabel 3 kelas eksperimen NHT adalah 3 rata-rata penigkatan kemampuan sedangkan skor gain minimum pada berpikir kritis siswa di kelas ekperimen kelas Round table lebih besar yaitu 7. Round table lebih tinggi dibandingkan Adapun skor gain maksimum pada kelas kelas eksperimen Numbered Heads Together, Pada kelas Numbered Heads Together didapatkan rata-rata sebesar 6,68, sedangkan rata-rata Gain pada kelas eksperimen Round table sebesar 10,2. Skor kenaikan gain minimum pada NHT adalah 12,00, sedangkan skor gain maksimum pada kelas round table lebih besar yaitu 14,00. Rata-rata gain kedua kelas tersebut digambarkan seperti pada gambar dibawah ini:

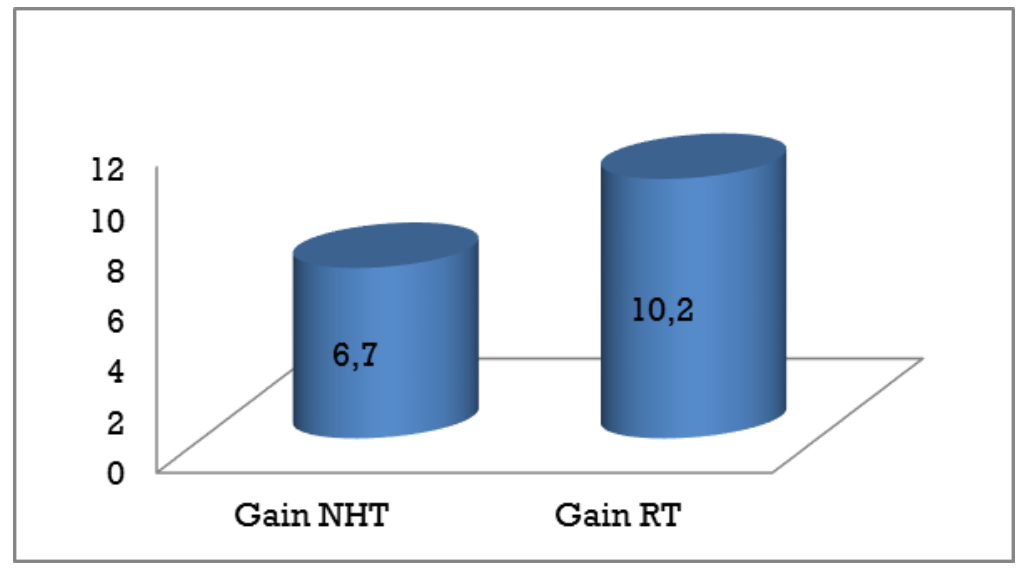

Gambar 3

Skor Gain kelas Eksperiman kelas NHT dan Round table 
Data N-Gain diperoleh dari hasil perhitungan dengan menggunakan data dari pretes dan postes, data N-Gain menunjukan peningkatan kemampuan siswa setelah mengikuti pembelajaran Numbered Heads Together dan Round Table. Deskrispi data N-Gain dapat dilihat pada tabel 5 berikut:

Tabel 5

Deskripsi Data N-Gain

\begin{tabular}{|l|r|r|r|r|r|}
\hline & $\mathrm{N}$ & \multicolumn{1}{|c|}{ Mean } & Std. Deviation & Minimum & Maximum \\
\hline NgainNHT & 35 & .5417 & .18724 & .25 & 1.00 \\
NgainRT & 35 & .7054 & .10232 & .50 & 1.00 \\
\hline
\end{tabular}

Berdasarkan data pada Tabel 5 Numbered Heads Together didapatkan rata-rata peningkatan kemampuan berpikir kritis pada peserta didik di kelas ekperimen Round table lebih tinggi dibandingkan kelas eksperimen Numbered Heads Together, Pada kelas rata-rata sebesar 0,54 , sedangkan ratarata $\mathrm{N}$-Gain pada kelas eksperimen Round table sebesar 0,70. Rata-rata Ngain kedua kelas tersebut digambarkan seperti pada gambar berikut:

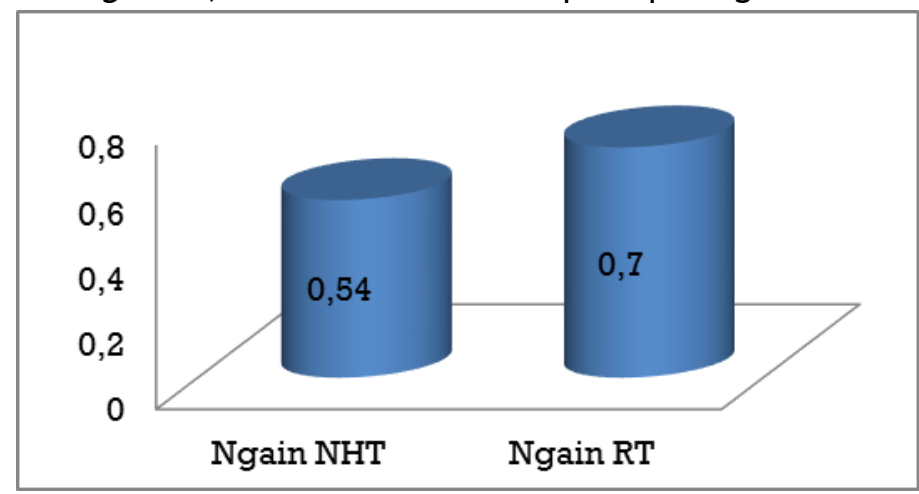

Gambar 4

Skor N-Gain kelas Eksperiman NHT dan Round table

Peningkatan kemampuan berpikir kritis siswa tidak hanya dilihat dari hasil peningkatan hasil post test, tetapi dilihat pula pada keaktifan siswa selama proses pembelajaran. Keaktifan siswa meliputi kemampuan siswa menyampaikan informasi, menyampaikan konsep dan ide, mengkaitkan teori dengan kondisi riil di lapangan, penyimpulan, serta kemampuan siswa dalam menyampaikan sudut pandang terhadap materi yang dipelajari. Data empirik perkembangan kemampuan berpikir kritis siswa pada kelas Numbered Heads Together (NHT) diperoleh hasil pada eksperimen pertama siswa yang aktif sebesar 20\% dari total siswa, pada eksperimen kedua meningkat menjadi $25 \%$, sedangkan pada eksperimen ketiga kembali mengalami peningkatan menjadi $37 \%$, dan pada eksperimen keempat menjadi 48\%. Berdasarkan hasil yang diperoleh, peningkatan kemampuan berpikir krits siswa pada kelas Numbered Heads Together (NHT) tidak terlalu tinggi. Hal ini dapat dilihat dari hasil kemampuan berpikir kritis siswa pada akhir eksperimen yang hanya mencapai $45 \%$, bahkan tidak mencapai setengah dari total siswa.

Data empirik perkembangan kemampuan berpikir kritis siswa pada kelas round table diperoleh hasil pada 
eksperimen pertama siswa yang sudah mampu berpikir kritis sebesar 25\% dari total siswa, pada eksperimen kedua meningkat menjadi 48\%,sedangkan pada eksperimen ketiga kembali mengalami peningkatan menjadi $60 \%$, dan pada eksperimen keempat menjadi 71\%. Berdasarkan hasil yang diperoleh, kemampuan berpikir krits siswa pada kelas round table mengalami peningkatan yang signifikan. Hal ini dapat dilihat dari hasil kemampuan berpikir kritis siswa pada akhir eksperimen yang hanya mencapai $71 \%$. Hal ini membuktian bahwa tipe round table lebih efektif dalam meningkatkan kemampuan berpikir kritis siswa dibandingkan dengan tipe Numbered Heads Together (NHT). Data yang telah diperoleh melalui pretes dan postes kemudian dihitung dan dianalisis untuk menentukan langkah selanjutnya dalam melakukan penelitian. Perhitungan dan analisis yang dilakukan meliputi uji homogenitas, uji normalitas dan uji hipotesis.

Uji hipotesis dihitung dengan menggunakan uji statistika (fungsi) $T$ independen yang terdapat pada program SPSS versi 20,00 for windows. Penjabaran mengenai hasil yang diperoleh dari penggunaan uji statistika tersebut disajikan dalam pembahasan pengujian hipotesis penelitian sebagai berikut:

\section{1) Hipotesis Pertama}

Tidak terdapat pebedaan yang signifikan kemampuan berpikir kritis siswa pada saat pretest pada siswa kelompok eksperimen NHT dengan siswa kelompok eksperimen round table. Hal ini dapat dilihat pada hasil yang diperoleh yaitu $T_{\text {hitung }}$ sebesar 1,565 dengan signifikansi 0.022 dimana signifikansi tersebut kurang dari 0.05 , artinya standar eror pada kelompok ini dibawah standar eror yang telah ditentukan dengan tingkat keppercayaan 95\%. Karena $\mathrm{T}_{\text {hitung }}$ $(1,565)<T_{\text {tabel }}(4,24)$ maka $H_{0}: \mu_{1} \neq \mu_{2}$ diterima dan $\mathrm{H}_{1}: \mu_{1}=\mu_{2}$ ditolak.

Jadi dapat disimpulkan bahwa tidak terdapat pebedaan kemampuan berpikir kritis siswa pada mata pelajaran ekonomi saat preetest pada siswa kelompok eksperimen yang proses pembelajarannya menggunakan model pembelajaran cooperative learning dengan tipe pembelajaran Numbered Heads Together (NHT) dengan siswa kelompok eksperimen yang proses pembelajarannya menggunakan pembelajaran model pembelajaran cooperative learning dengan tipe pembelajaran Round Table.

\section{2) Hipotesis Kedua}

Hipotesis kedua, bahwa terdapat perbedaan yang signifikan pada peningkatan kemampuan berpikir kritis siswa pada kedua kelompok eksperimen setelah dilakukan perlakuan. Hal ini dapat dilihat pada hasil yang diperoleh yaitu $T_{\text {hitung }}$ sebesar 7.060 dengan signifikansi 0.02 , artinya standar eror pada kelompok ini dibawah standar eror yang telah ditentukan dengan tingkat kepercayaan $95 \%$. Karena $T_{\text {hitung }}(7,060)$ $>\mathrm{T}_{\text {tabel }}(4,24)$ maka $\mathrm{H} 1: \mu 1 \neq \mu 2$ diterima dan $\mathrm{H} 0: \mu 1=\mu 2$ ditolak.

Jadi dapat disimpulkan bahwa terdapat pebedaan kemampuan berpikir kritis siswa pada mata pelajaran ekonomi saat akhir pembelajaran setelah perlakuan pada siswa kelompok eksperimen yang proses pembelajarannya menggunakan model pembelajaran cooperative learning dengan tipe pembelajaran Numbered Heads Together (NHT) dengan siswa kelompok eksperimen yang proses pembelajarannya menggunakan pembelajaran model pembelajaran cooperative learning dengan tipe pembelajaran Round Table. 


\section{3) Hipotesis ketiga}

Hipotesis ketiga, kemampuan berpikir kritis siswa yang menggunakan tipe rond table lebih baik daripada kelas yang menggunakan tipe numbered heads together (NHT). Hal ini dapat dilihat pada hasil yang diperoleh yaitu $\mathrm{T}_{\text {hitung }}$ sebesar 5,209 dengan signifikansi 0.007 , artinya standar eror pada kelompok ini dibawah standar eror yang telah ditentukan dengan tingkat keppercayaan $95 \%$ Karena $\mathrm{T}_{\text {hitung }}$ $(5,209)>$ Ttabel $(4,24)$ maka $\mathrm{H} 1: \mu 1 \neq$ $\mu 2$ diterima dan $\mathrm{H} 0: \mu 1=\mu 2$ ditolak. Jadi dapat disimpulkan bahwa model pembelajaran kooperatif tipe round table lebih baik daripada tipe numbered heads together (NHT) dalam meningkatkan kemampuan berpikir kritis siswa pada mata pelajaran ekonomi.

Hasil pengujian hipotesis dari penelitian ini diperoleh bahwa Model cooperative learning tipe round table lebih efektif dalam meningkatkan kemampuan berpikir kritis siswa dari pada tipe numbered heads together. Hal ini sesuai dengan pernyataan Ellen Weber (1997) bahwa dalam metode round table dilontarkan sebuah pertanyaan kritis atau suatu masalah guna menciptakan aktivitas berpikir bagi siswa. Selain itu Weber mengungkapkan bahwa metode pembelajaran round table memiliki manfaat tambahan bagi siswa untuk terlibat dalam pemikiran yang kritis. Dalam banyak hal, gaya ini merupakan lingkaran diskusi gaya berbicara, di mana setiap siswa memiliki kesempatan untuk berpartisipasi melalui berbicara dan mendengarkan rekan-rekan mereka.

Dari data yang telah dibahas
pada pembahasan sebelumnya
diperoleh kesimpulan bahwa kelas
eksperimen yang menggunakan tipe
round table memiliki skor N-Gain lebih

daripada skor gain kelas Numbered heads together (NHT). Hal ini membuktikan bahwa terdapat perbedaan kemampuan berpikir kritis yang signifikan antara kelas yang menerapkan model pembelajaran Cooperative Learning tipe Numbered heads together (NHT) dengan kelas eksperimen yang menggunakan model pembelajaran Cooperative Learning tipe round table. Peningkatan kemampuan berpikir kritis tersebut dilihat dari skor N-Gain yang dicapai setiap siswa. Rata-rata skor N-Gain pada kelompok eksperimen round table menunjukan rata-rata yang lebih tinggi dibandingkan dengan kelompok yang menggunakan tipe Numbered heads together (NHT). Jadi dalam penelitian ini tipe round table lebih baik daripada tipe numbered heads together dalam meningkatkan kemampuan berpikir kritis siswa.

\section{Kesimpulan dan Saran}

\section{1) Kesimpulan}

Berdasarkan hasil eksperimen yang dilakukan pada kelas kontrol dan eksperimen kelas XI SMAN 1 Kuningan, maka dapat ditarik kesimpulan sebagai berikut:

a) Tidak terdapat pebedaan kemampuan berpikir kritis siswa pada mata pelajaran ekonomi saat pretest pada siswa kelompok eksperimen yang proses pembelajarannya menggunakan model pembelajaran cooperative learning dengan tipe pembelajaran Numbered heads together (NHT) dengan siswa kelompok eksperimen yang proses pembelajarannya menggunakan model pembelajaran cooperative learning dengan tipe pembelajaran round table. 
b) Terdapat perbedaan peningkatan kemampuan berpikir kritis siswa pada mata pelajaran ekonomi saat posttest pada siswa kelompok eksperimen yang proses pembelajarannya menggunakan model pembelajaran cooperative learning dengan tipe pembelajaran tipe pembelajaran Numbered heads together (NHT) dengan siswa kelompok eksperimen yang proses pembelajarannya menggunakan model pembelajaran cooperative learning dengan tipe pembelajaran round table.

c) Model pembelajaran kooperatif tipe round table lebih efektif daripada tipe numbered heads together (NHT) dalam meningkatkan kemampuan berpikir kritis siswa pada mata pelajaran ekonomi.

2) Saran

Oleh karena itu dapat disampaikan saran sebagai berikut:
a) Bagi guru
menggunakan
pembelajaran
sebaiknya model
Cooperative learning tipe numbered heads together dan round table sebagai alternatif tipe dalam mengajar. Tipe round table lebih efektif

digunakan untuk meningkatkan kemampuan berpikir kritis siswa, sedangkan untuk membantu meningkatkan pemahaman konsep siswa terhadap materi yang diajarkan dapat menggunakan tipe Numbered Heads Together (NHT).

b) Bagi pihak sekolah atas kebijakan Kepala sekolah sebagai policy maker, hendaknya menganjurkan kepada para guru untuk mengikuti berbagai seminar, lokokarya, semiloka, dan diklat, terutama yang berkenaan dengan pendalaman metode pembelajaran, sehingga inovasiinovasi dalam pembelajaran semakin berkembang yang pada akhirnya hasil belajar dan kemampuan berpikir kritis siswa semakin meningkat.

c) Bagi penelitian selanjutnya, diharapkan dapat menggunakan model pembelajaran cooperative learning tipe numbered heads together dan round table dalam meningkatkan kemampuan berpikir kritis dan pemahaman konsep pada pembahasan yang berbeda.

\section{Sumber Buku:}

\section{Daftar Pustaka}

Anita, Lie. 2008. Cooperative Learning. Jakarta. Gramedia Widiasarana Indonesia.

Bambang, Supomo. 2008. Metodologi penelitian Bisnis. Yogyakarta. BFEE UGM.

Davis, Gary A. ( 2012 ): Anak Berbakat dan Pendidikan Keberbakatan, PT Indeks, Jakarta.

Djamarah, S. B. (2010). Psikologi Belajar. Jakarta: Rineka Cipta.

Etin, Solihatin dan Raharjo. 2007. Cooperative Learning, Analisis Pembelajaran IPS . Jakarta: PT Bumi Aksara.

Fisher, Alec. penerjemah Benyamin Hadinata. 2009. Berpikir kritis sebuah teori dan pengantar. Jakarta : Erlangga. 
Gay Geogffrey e. Mills, Peter Airasian. 2006. Educational research competencies for analysis and applications. Columbus Ohio : Upper saddle river (New Jersey).

Harry, Firman dan Ari Widodo. 2008. Penilaian Hasil belajar dalam pembelajaran Kimia. UPI.

Isjoni, 2010. Cooperative learning. Bandung : Alfabeta.

Kokom, Komalasari. 2010. Pembelajaran Kontekstual. Bandung: Refika Aditama Pembelajaran kontekstual.

Muh Nur, Prima Retno Wikandari, dan Bambang Sugiarto. 2004. Teori2 Pembelajaran Kognitif Sugiarto. Surabaya: University Press.

Nana, Syaodih Sukmadinata. 2007. Metode Penelitian Pendidikan Bandung: PT Remaja. Rosdakarya.

Neti Budiwati dan Leni Permana. 2010. Perencanaan pembelajaran Ekonomi. Bandung : Laboratorium ekonomi dan Koperasi.

Ollila, Julie. (2017). Social Studies in Curriculum Integration in Elementary Classroom: A Case Study on a Pennsylvania Rural School. Jouirnal of Social Studies. http. Odi.org/10.1016/j.jssr.208.02.001 diakses March, 6. 2018.

Paul, Suparno. 2007. Metodologi Pembelajaran Fisika Konstruktivistik, Yogyakarta: Penerbit USD.

Robert Slavin. 2005. Cooperative learning, teori, riset dan praktik. Bandung: Nusamedia.

Sanjaya, Wina. 2006. Strategi Pembelajaran:Berorientasi Standar Proses Pendidikan, Bandung: CV Prenada Media Group.

Sofan, Amri. dkk. 2010. Proses Pembelajaran. Jakarta: Prestasi Pustaka.

Sugiyono. 2008. Metode Penelitian Pendidikan. Bandung: Alfabeta.

Suharsimi, Arikunto. 2006. Prosedur penelitian suatu pendekatan praktik. Jakarta: Rineka Cipta.

Syaiful, Sagala. 2009. Konsep dan Makna Pembelajaran. Bandung: CV Alfabeta.

Triantoro, 2007. Teori Kognitif Perilaku, Jakarta: Graha IImu.

Wade, Carol. 2009. Psikologi. Erlangga. Jakarta.

Weber, E. (1997). Roundtable learning: Building understanding through enhanced MI strategies. Tucson, AZ: Zephyr Press.

\section{Situs Internet:}

Ibrahim. 2000. Penerapan-model-pembelajaran-kooperatif. www.tuanguru.net.

Lubis, Brando. 2010. Berpikir kritis. http://edukasi.kompasiana.com

Mudjia Rahardjo, $2010 . \quad$ Melatih-Berpikir-Kritis.

http://mudjiarahardjo.com/artikel/169-.html

Setiono, Agustinus. 2007. Berpikir Kritis. http://agustinussetiono.wordpress.com

Sutrisno, Leo. 2010. Berpikir kritis. http://www.borneotribune.com 